(c) American Dairy Science Association, 2003.

\title{
Relationships Among Milk Yield, Body Condition, Cow Weight, and Reproduction in Spring-Calved Holstein-Friesians
}

\author{
F. Buckley*, K. O’Sullivan†, J. F. Mee*, R. D. Evans*, and P. Dillon* \\ *Dairy Production Research Centre, Teagasc, Moorepark, Fermoy, Co. Cork, Ireland \\ †Statistical Laboratory, Dept. of Statistics, University College Cork, Ireland
}

\begin{abstract}
Relationships among milk production, body condition score (BCS), body weight (BW), and reproduction were studied using logistic regression on data from 6433 spring-calving Holstein-Friesian dairy cows in 74 commercial herds. Multivariate models were adjusted for herd, breeding value for milk yield, proportion of Holstein-Friesian genes, lactation number, calving period, and degree of calving assistance. Significant associations between reproductive measures and components of energy balance were identified. Higher 200$\mathrm{d}$ milk protein content and higher protein-to-fat ratio at start of breeding were associated with increased likelihood of submission for breeding in the first $21 \mathrm{~d}$ of the breeding season (SR21). High 100-d cumulative milk yield as a proportion of estimated 305-d milk yield (low persistency) was associated with a lower likelihood of pregnancy to first service (PREG1), whereas cows reaching peak milk yields earlier tended to have higher PREG1. Cows that reached nadir milk protein content relatively late in lactation had lower PREG1. Milk yield at first service and 305-d milk protein content were positively associated with the likelihood of pregnancy after $42 \mathrm{~d}$ of breeding (PR42). Higher 305-d milk lactose content was associated with increased PREG1 and PR42. Mean BCS at 60 to 100 $\mathrm{d}$ of lactation was positively associated with both SR21 and PR42, whereas nadir BCS was positively associated with PREG1. Cows with precalving BCS > 3.0 that also lost $>0.5 \mathrm{BCS}$ unit by first service had lower PR42. More BW gain for $90 \mathrm{~d}$ after start of breeding was associated with higher SR21 and PREG1; more BW gain for $90 \mathrm{~d}$ after first service was associated with higher PR42. Milk protein and lactose content, BCS, and BW changes are important tools to identify cows at risk of poor reproduction.
\end{abstract}

(Key words: body condition score, logistic regression, negative energy balance, reproduction)

Received February 25, 2002.

Accepted October 10, 2002.

Corresponding author: Frank Buckley; e-mail: fbuckley@ moorepark.teagasc.ie.
Abbreviation key: DairyMIS = Dairy Management Information System, IDRC = Irish Dairy Recording Cooperative, $\mathbf{N E B}=$ negative energy balance, $\mathbf{O R}=$ odds ratio, PREG1 = pregnant to first service, PR42 = pregnant after $42 \mathrm{~d}$ of the breeding season, $\mathbf{S R 2 1}=$ submission for breeding in the first $21 \mathrm{~d}$ of the breeding season.

\section{INTRODUCTION}

Milk production systems in Ireland are primarily pasture-based and involve seasonal calving (Dillon et al., 1995). In a typical seasonal herd in Ireland, breeding starts on a fixed calendar date in spring between late April and early May. The key breeding objective is to achieve the highest pregnancy rate in the shortest period of time after the start of the breeding season in order to achieve a concentrated calving pattern during the following season (O'Farrell, 1994). This is also required to maintain a calving interval of around $365 \mathrm{~d}$.

After parturition, dairy cows experience a rapid increase in milk yield, a slow rise in DMI, and increased mobilization of body adipose tissue (Garnsworthy, 1988; Nebel and McGilliard, 1993). It is normal for dairy cows to undergo a process of adipose tissue mobilization in early lactation (Bauman and Currie, 1980) because energy demand for milk production is greater than the energy provided by the diet. The severity and duration of the negative energy balance (NEB) may be influenced by genetic merit for milk yield (Grainger et al., 1985; Veerkamp et al., 1994; Buckley et al., 2000a) and energy density or quantity of the feed offered (Cowan, 1982). Gibb et al. (1992) equated the contribution of mobilized adipose tissue to a nutrient supply sufficient to produce almost $500 \mathrm{~kg}$ of milk over the first 8 wk of lactation with cows of average production levels. The reproductive performance of cows, particularly the probability of conception, may be negatively associated with the magnitude and duration of NEB in early lactation (Villa-Godoy et al., 1988; Butler and Smith, 1989; Nebel and McGilliard, 1993; Senatore et al., 1996; Domecq et al., 1997). Butler and Smith (1989) showed that cows who lost 0.5 to 1.0 point in BCS between parturition and first service achieved a 
pregnancy rate at first service (PREG1) of 53\%, while those losing $>1.0$ point achieved a PREG1 of $17 \%$.

The rate of genetic improvement for milk production per cow in Ireland up to about 1985 was low (approximately $0.5 \%$ per year; Department of Agriculture, Food, and Forestry, 1994) but since then has increased markedly. Phenotypic trends in calving rate to first service in Irish dairy herds have shown a significant decline of around 0.9 percentage unit per year between 1991 and 1998 (Mee et al., 1999). Cows that are genetically superior milk producers tend to have genetically lower BCS throughout lactation (Veerkamp and Brotherstone, 1997; Buckley et al. 2000b). Similarly, cows of higher genetic merit for milk production generally have greater BCS loss in early lactation than those of lower genetic merit (Grainger et al., 1985; Veerkamp et al., 1994; Buckley et al., 2000a). Veerkamp et al. (2001) showed that increasing Holstein-Friesian genes from 50 to $100 \%$ decreased BCS by 1 unit on a scale of 1 to 9 . In the present study, both the proportion of Holstein-Friesian genes and genetic merit for milk production were adjusted for in the analysis, with the objective of investigating the influence of management factors on reproductive performance. Therefore, the objective of this study was to determine whether milk production, BCS or BCS change, and BW or BW change were associated with the likelihood of detected estrus and insemination in $21 \mathrm{~d}$ (submission rate of the breeding season; SR21), PREG1, or pregnancy in $42 \mathrm{~d}$ (PR42), when adjusting for factors, such as herd, lactation number, calving period, breeding value for milk yield, proportion of Holstein-Friesian genes, and degree of calving assistance.

\section{MATERIALS AND METHODS}

The study comprised 74 spring-calving dairy herds with 6433 cows with fertility records. The data were recorded during 1999. The average herd size was 87 cows with a range from 25 to 235 . The herds were representative of Irish pasture-based seasonal calving herds in which good practices for health and reproductive management were implemented. Prebreeding estrus detection was practiced on $88 \%$ of the farms. Ninety-two percent of farmers observed cows more than twice daily for estrus during the breeding season, while $99 \%$ of farmers used tail paint and/or a vasectomized bull as an aid to estrus detection. Detailed information on the use of fertility treatments was available from 49 herds (4920 cows). During the course of the breeding season, $21 \%$ of these cows received some form of fertility treatment of which $38 \%$ involved the use of an intravaginal progesterone-releasing device (PRID, Sanofi Animal Health, 33501 Libourne Cedex France, or CIDR, InterAg, Hamilton, New Zealand) and 57\% the use of a prostaglandin regimen. Concentrate supplementation levels per cow averaged $745 \mathrm{~kg}$ with a range from 335 to $1305 \mathrm{~kg}$ for individual farms. All herds were incorporated into the Dairy Management Information System (DairyMIS) run by Moorepark (Crosse, 1986). The DairyMIS is a recorder-based computerized system collecting detailed stock, farm inputs, production, and reproduction information on a monthly basis.

\section{Data Collection}

Three reproductive variables were calculated: SR21, PREG1, and PR42. The 21-d submission rate included all cows available for breeding that were calved $30 \mathrm{~d}$ before the herd start of breeding date. Outcome of first insemination was used for PREG1 irrespective of when it occurred during the breeding season. Calculation of PR42 included all cows available for breeding that were calved on or before d 41 of the breeding season. At the start of the breeding season 104 cows (1.6\% of the potential 6557 in the data set) were identified as not available for breeding. Beginning 40 to $50 \mathrm{~d}$ after the start of the breeding season, all herds were visited on three or four occasions, at approximately 40-d intervals, to perform pregnancy diagnosis by transrectal ultrasound imaging (Aloka 210D*II, 7.5 MHz). Cows inseminated greater than $28 \mathrm{~d}$ and not observed in estrus again after insemination were scanned to confirm pregnancy. Subsequently, all cows in the study were determined to be pregnant or not by rectal palpation at least $56 \mathrm{~d}$ after the end of the defined breeding season.

Test-day records for each individual cow were obtained from the Irish Dairy Recording Cooperative (IDRC). Milk recording was carried out in each herd at 4 -wk intervals. The lactation number of each cow was also obtained from the IDRC files. Calving date records were captured through the DairyMIS system. The calving date and drying date (also obtained from the IDRC files) were used to validate lactation number and test-day records for a given lactation. Calving difficulty information was recorded on standardized sheets and entered through the DairyMIS system.

Fifty-one of the 74 farms were visited seven to eight times from mid-January to mid-September to record BCS and BW. Visits were at intervals of 2.5 to $5 \mathrm{wk}$ with visits being more frequent in early lactation. Each BW was recorded electronically, using portable weighing scales and Winweigh software package (Trutest limited, Aukland, New Zealand). The scales were calibrated weekly against permanent scales at the Dairy Production Research Centre and were calibrated 
again with known weights on arrival at each farm. Body condition scores were on a scale of 1 to $5(1=$ emaciated, 5 = extremely fat) with increments of 0.25 (Lowman et al., 1976).

The breeding value for milk yield and the proportion of Holstein-Friesian genes for each sire/maternal grand sire contained in the dataset were provided by Holstein UK and Ireland. The proportion of HolsteinFriesian genes for individual cows was calculated as $0.5 \cdot$ sire plus $0.25 \cdot$ maternal grand sire, assuming that maternal grand dams to have zero Holstein-Friesian genes. The latter was assumed because most dams and their proportion of Holstein-Friesian genes were unknown; in addition, the base population in Ireland before the mid-eighties was predominantly British Friesian genes. The proportion of Holstein-Friesian genes was available for all sires in the data set. However, it was only available for $50 \%$ of maternal grand sires and was assumed to be zero as these bulls were available pre-1980 and were not present in the data set (personal communication Matt Winters, Holstein UK and Ireland, Scotsbridge House, Rickmansworth, Herts, WD3 3BB). The breeding value for milk yield (predicted difference for milk yield) for individual cows in the study was calculated similar to the proportion of Holstein-Friesian genes. However, as for the proportion of Holstein-Friesian genes, breeding value for milk yield values were unavailable for $50 \%$ of maternal grand sires. As a result breeding value for milk yield could not be estimated for $36 \%$ of the individual cows.

\section{Data Handling}

Data were processed with Microsoft Access 97. Before appending the various individual datasets, a unique cow and herd identifier was attached to each record. Data handling included the identification of anomalies, such as duplicate records, incomplete records, as well as creating the specific milk production, $\mathrm{BCS}, \mathrm{BW}$, and reproductive variables. All independent variables were either quartiled or categorized into biologically plausible groups.

From the test records obtained from the IDRC, variables, such as estimated 305-d and 200-d yields, milk composition, peak yield, nadir milk protein content, DIM at which nadir/peak yield occurred, and variables relating to critical management periods, e.g., yield nearest to first insemination, measures of persistency of lactation, e.g., estimated 100-d cumulative milk yield as a proportion of the estimated 305-d cumulative milk yield were calculated. Cumulative 305-d milk yields and composition estimates were calculated as the mean of greater than or equal to five test-day records multiplied by 305 , with the last test not later than $325 \mathrm{~d}$ into lactation. A total of 33 milk production variables were created. All of these milk variables were quartiled. The lactation number was categorized as lactation 1 , lactation 2 , or greater than or equal to lactation 3. Calving dates were categorized into four calving periods: January, February, March/April, and May or later.

Sixteen BCS or BCS change variables and $16 \mathrm{BW}$ or BW change variables were created. These included BCS or BW variables at key periods in lactation, such as precalving, at first service, at herd start of breeding date, nadir BCS/BW, DIM at which nadir was recorded, average BCS/BW between 60 and $100 \mathrm{~d}$ of lactation, and so forth. The BCS and BW changes were also calculated, such as from precalving to key periods thereafter and changes from key periods in lactation to later in lactation. All BW variables were quartiled. The BCS variables were predominantly grouped into selected categories.

Values for breeding value for milk yield were quartiled. The proportion of Holstein-Friesian genes was categorized into three groups: cows with less than 50, 50 , and $>50 \%$ Holstein-Friesian genes.

The degree of calving assistance was categorized into two groups. Category 1 included cows that were unobserved calving or that were observed and unassisted at calving, while category 2 included cows that received some assistance and cows that had a high degree of difficulty, culminating in the use of a calving aid or veterinary assistance.

\section{Statistical Analyses}

The dependent variables investigated (SR21, PREG1, and PR42) were binary data $(0,1)$. The statistical procedure implemented was logistic regression (Kleinbaum, 1994) using SPSS (SPSS, 1999). As indicated previously, each independent variable of interest was quartiled or categorized into three or four groups. One of these groups was designated as the reference category for odds ratio $(\mathbf{O R}=1)$. An OR of $>1$ implies increased likelihood and an OR $<1$ implies an inverse association. In this analysis, the reproductive success for each category of independent variable was compared to the reproductive success of the reference group for that variable.

Adjustment variables were selected on the basis of biological plausibility. Univariate analysis was carried out to determine the associations between the adjustment and the reproductive variables.

Separate logistic regression models were developed for each of the three dependent variables (SR21, PREG1, and PR42) and within each of these separate models for the three sets of independent variables 
Table 1. Number of cows available (n), min., max., mean, and SD for a range of milk production, BCS, BW, and adjustment variables.

\begin{tabular}{|c|c|c|c|c|c|}
\hline & $\mathrm{n}$ & Min. & Max. & Mean & $\mathrm{SD}$ \\
\hline \multicolumn{6}{|l|}{ Milk production } \\
\hline Estimated $305-\mathrm{d}$ milk yield (kg/cow) & 5374 & 2660 & 11622 & 6557 & 1140.1 \\
\hline Estimated 305-d fat yield (kg/cow) & 5374 & 83 & 463 & 246 & 44.6 \\
\hline Estimated 305-d fat concentration $(\mathrm{g} / \mathrm{kg})$ & 5374 & 23.8 & 57.7 & 37.6 & 4.3 \\
\hline Estimated $305-\mathrm{d}$ protein concentration $(\mathrm{g} / \mathrm{kg})$ & 5374 & 24.8 & 43.9 & 34.0 & 2.1 \\
\hline Estimated 305-d lactose concentration (g/kg) & 5178 & 38.2 & 50.6 & 46.0 & 1.3 \\
\hline \multicolumn{6}{|l|}{ BCS } \\
\hline BCS change between precalving and first service & 4040 & -1.75 & 1.00 & -0.51 & 0.35 \\
\hline BCS change between first service and $90 \mathrm{~d}$ thereafter & 4636 & -1.25 & 1.75 & 0.05 & 0.30 \\
\hline Nadir BCS & 5062 & 1.25 & 4.25 & 2.63 & 0.35 \\
\hline \multicolumn{6}{|l|}{ BW } \\
\hline Precalving BW (kg) & 4041 & 373 & 964 & 625 & 74.5 \\
\hline BW at first service $(\mathrm{kg})$ & 5094 & 333 & 780 & 538 & 66.2 \\
\hline BW change between precalving and first service (kg) & 4037 & -304 & 146 & -86 & 40.7 \\
\hline Lactation number ( 1 to $5+$ ) & 6191 & 1 & 5 & 2.9 & 1.49 \\
\hline Proportion of Holstein-Friesian genes & 6110 & 0 & 75 & 51 & 20.9 \\
\hline Breeding value for milk yield & 3919 & -321 & 423 & 77 & 112.7 \\
\hline
\end{tabular}

(milk production, BCS, and BW). The model building process involved several steps. First, a series of septivariate logistic regression models were constructed (six adjustment variables plus one independent variable). At this stage, only cows that had a value for all variables within each of the nine sets of analyses were used. Variables that had a $P$-value of less than or equal to 0.25 were retained for backward stepwise logistic regression. The outcome of this step was used to construct the final models describing the individual dependent variables as functions of milk production, BCS, and BW. Once the final models were constructed they were rerun incorporating the maximum number of cows, i.e., all cows that had a value for each of the retained independent variables. Multicollinearity among independent variables in each model was investigated (Montgomery et al., 2001) and found not to be a problem. A coefficient of determination (adjusted $R^{2}$ ) was used to estimate the proportion of variation explained by each model (Nagelkerke, 1991).

\section{RESULTS}

Table 1 includes minimums, maximums, means, and standard deviations for milk production, BCS, BW, and adjustment variables for cows across herds. Averages for SR21, PREG1, and PR42 were 81, 49, and $57 \%$, respectively. However, there was large variation among herds, with actual herd averages ranging from 41 to $96 \%, 26$ to $87 \%$, and 19 to $96 \%$ for SR21, PREG1, and PR42, respectively. Of the cows with a record for degree of calving assistance, 95\% calved unassisted and $5 \%$ required some assistance.

The associations (univariate analysis) between the adjustment variables; calving period, lactation number, proportion of Holstein-Friesian genes, breeding value for milk yield, degree of calving assistance, and the dependent variables (SR21, PREG1, and PR42) are presented in Tables 2, 3, and 4. Significant associations were observed between herd and calving period and all dependent variables $(P<0.001)$. Lactation number and degree of calving assistance were not associated with SR21 but were associated with both of the pregnancy variables (PREG1 and PR42) $(P<0.001)$. Higher proportions of Holstein-Friesian genes and higher breeding values for milk yield were both significantly associated with lower SR21 and PR42, while no association was found with PREG1.

\section{Milk Production and SR21}

Of the milk production variables investigated, those associated with the likelihood of SR21 included estimated 200-d milk protein content and protein-to-fat ratio at herd start of breeding date (Table 5). Cows with a higher estimated 200-d milk protein content (third and fourth quartiles) had an increased likelihood of SR21 (OR = 1.52 and 1.54, $P \leq 0.012)$ compared with cows in the reference (lowest) category $(<31.8 \mathrm{~g} /$ $\mathrm{kg})$. Cows with a higher protein-to-fat ratio at herd start of breeding date tended to have a significantly 
Table 2. Association (univariate logistic regression) between adjustment variables and SR21. ${ }^{1}$

\begin{tabular}{llll}
\hline Variable & OR & $95 \%$ CI & $P$-value \\
\hline $\begin{array}{l}\text { Calving period }(\mathrm{n}=4669) \\
\text { January }\end{array}$ & 1 & & \\
$\quad$ February & 1.04 & $0.84-1.28$ & $\mathrm{NS}$ \\
$\quad$ March/April & 0.75 & $0.61-0.92$ & 0.006 \\
$\quad$ May+ & 0.60 & $0.47-0.78$ & $<0.001$ \\
Lactation number $(\mathrm{n}=5001)$ & & & \\
1 & 1.02 & $0.85-1.22$ & $\mathrm{NS}$ \\
2 & 0.92 & $0.77-1.11$ & $\mathrm{NS}$ \\
$3+$ & 1 & & \\
Holstein \% $(\mathrm{n}=4932)$ & & & \\
$<50$ & 1 & & $\mathrm{NS}$ \\
50 & 0.88 & $0.71-1.08$ & 0.029 \\
$>50$ to $<75$ & 0.81 & $0.67-0.98$ & 0.001 \\
$75 \%$ & 0.68 & $0.54-0.86$ & \\
Pdmilk $(\mathrm{kg})(\mathrm{n}=3184)$ & & & $\mathrm{NS}$ \\
$\quad<+6$ & 1 & & $\mathrm{NS}$ \\
$\quad+6$ to +91 & 1.12 & $0.85-1.47$ & 0.002 \\
$\quad+92$ to +155 & 0.88 & $0.68-1.15$ & \\
$>+155$ & 0.67 & $0.52-0.86$ & \\
Calving difficulty $(\mathrm{n}=5025)$ & & & $\mathrm{NS}$ \\
$\quad$ No assistance & 1 & & \\
Assistance & 0.88 & $0.64-1.21$ & \\
\hline
\end{tabular}

${ }^{1}$ SR21 = Submission in the first $3 \mathrm{wk}$ of the breeding season, OR $=$ odds ratio, $\mathrm{CI}=$ confidence interval, $\mathrm{NS}=P>0.10$.

higher likelihood of SR21. The adjusted $\mathrm{R}^{2}$ for the model was 0.164 .

\section{BCS, BW, and SR21}

Lower average BCS (2.5 or less) between 60 and 100 $\mathrm{d}$ of lactation was associated with a lower chance of

Table 3. Association (univariate logistic regression) between adjustment variables and PREG1. ${ }^{1}$

\begin{tabular}{|c|c|c|c|}
\hline Variable & OR & $95 \% \mathrm{CI}$ & $P$-value \\
\hline \multicolumn{4}{|c|}{ Calving period $(\mathrm{n}=5639)$} \\
\hline January & 1 & & \\
\hline February & 0.99 & $0.86-1.15$ & NS \\
\hline March/April & 0.76 & $0.66-0.89$ & $<0.001$ \\
\hline May+ & 0.56 & $0.48-0.65$ & $<0.001$ \\
\hline \multicolumn{4}{|c|}{ Lactation number $(\mathrm{n}=6187)$} \\
\hline 1 & 1.29 & $1.14-1.46$ & $<0.001$ \\
\hline 2 & 1.00 & $0.88-1.13$ & NS \\
\hline $3+$ & 1 & & \\
\hline \multicolumn{4}{|c|}{ Holstein \% $(\mathrm{n}=6106)$} \\
\hline$<50$ & 1 & & \\
\hline 50 & 1.07 & $0.93-1.23$ & NS \\
\hline$>50$ to $<75$ & 1.05 & $0.92-1.19$ & NS \\
\hline $75+$ & 0.95 & $0.81-1.12$ & NS \\
\hline \multicolumn{4}{|c|}{ Pdmilk (kg) (n = 3918) } \\
\hline$<+6$ & 1 & & \\
\hline+6 to +91 & 1.05 & $0.88-1.25$ & NS \\
\hline+92 to +155 & 1.13 & $0.94-1.34$ & NS \\
\hline$>+155$ & 0.90 & $0.76-1.08$ & NS \\
\hline \multicolumn{4}{|c|}{ Calving difficulty $(\mathrm{n}=6222)$} \\
\hline No assistance & 1 & & \\
\hline Assistance & 0.64 & $0.51-0.81$ & $<0.001$ \\
\hline
\end{tabular}

${ }^{1} \mathrm{PREG} 1=$ pregnant to first service, $\mathrm{OR}=$ odds ratio, $\mathrm{CI}=$ confidence interval, $\mathrm{NS}=P>0.10$.
Table 4. Association (univariate logistic regression) between adjustment variables and PR42. ${ }^{1}$

\begin{tabular}{llll}
\hline Variable & OR & $95 \%$ CI & $P$-value \\
\hline $\begin{array}{l}\text { Calving period }(\mathrm{n}=5615) \\
\text { January }\end{array}$ & 1 & & \\
$\quad$ February & 1.00 & $0.85-1.18$ & $\mathrm{NS}$ \\
$\quad$ March/April & 0.71 & $0.60-0.83$ & $<0.001$ \\
$\quad$ May+ & 0.26 & $0.22-0.30$ & $<0.001$ \\
Lactation number $(\mathrm{n}=6148)$ & & & \\
1 & 1.65 & $1.45-1.88$ & $<0.001$ \\
2 & 1.09 & $0.96-1.24$ & $\mathrm{NS}$ \\
$3+$ & 1 & & \\
Holstein \% $(\mathrm{n}=6069)$ & & & \\
$<50$ & 1 & & $\mathrm{NS}$ \\
50 & 0.98 & $0.85-1.13$ & $\mathrm{NS}$ \\
$\quad 50$ to $<75$ & 0.97 & $0.85-1.34$ & 0.003 \\
$75+$ & 0.78 & $0.67-0.92$ & \\
Pdmilk $(\mathrm{kg})(\mathrm{n}=3897)$ & 1 & & $\mathrm{NS}$ \\
$\quad<+6$ & 1.13 & $0.94-1.36$ & $\mathrm{NS}$ \\
$\quad+6$ to +91 & 1.12 & $0.93-1.34$ & \\
$\quad+92$ to +155 & 0.81 & $0.68-0.97$ & 0.023 \\
$>+155$ & & & \\
Calving difficulty $(\mathrm{n}=6180)$ & 1 & & $<0.001$ \\
$\quad$ No assistance & 0.60 & $0.48-0.76$ & \\
Assitance &
\end{tabular}

${ }^{1} \mathrm{PR} 42=$ pregnant after $42 \mathrm{~d}$ of the breeding season, $\mathrm{OR}=$ odds ratio, $\mathrm{CI}=$ confidence interval, $\mathrm{NS}=P>0.10$.

SR21 compared with the reference group that had a BCS of 2.75 to $3.0(\mathrm{OR}=0.59, P<0.001$; Table 5$)$. This corresponds to an estimated reduction in submission rate of 8 percentage units compared with the reference category. When BCS between 60 and $100 \mathrm{~d}$ of lactation was greater than 3.0, the likelihood of SR21 did not differ. The adjusted $R^{2}$ for the model was 0.131 .

Cows with a very high BW ( $>576 \mathrm{~kg})$ had a higher likelihood of SR21 compared with those with the lowest BW $(<483 \mathrm{~kg})$ (Table 5). Cows losing more than $131 \mathrm{~kg}$ from precalving to nadir BW had a lower likelihood of SR21 than cows losing between 110 and 131 $\mathrm{kg}$. Cows gaining $>34 \mathrm{~kg}$ between start of breeding date and $90 \mathrm{~d}$ thereafter (more positive energy balance) tended to have a higher likelihood of SR21 compared with cows gaining less than $17 \mathrm{~kg}$. The adjusted $\mathrm{R}^{2}$ for the model was 0.194 .

\section{Milk Production and PREG1}

There was a tendency for cows with a high estimated 305-d solids-corrected milk yield to have an improved likelihood of PREG1 (Table 6). A high 100-d cumulative milk yield as a proportion of the estimated 305-d cumulative milk yield (low persistency) was associated with a lower chance of PREG1 $(\mathrm{OR}=0.72, P=0.012)$. Cows that reached peak milk yield earliest in lactation (reference category; $<98 \mathrm{~d}$ ) tended to have a higher likelihood of PREG1 when compared to the other three quartiles $(\mathrm{OR}=0.62,0.76,0.70, P \leq 0.05)$. A high esti- 
Table 5. Association between milk production, BCS, and BW variables, and SR21. ${ }^{1}$

\begin{tabular}{|c|c|c|c|}
\hline Model $^{2}$ & OR & $95 \% \mathrm{CI}$ & $P$-value \\
\hline & Estimated $200-\mathrm{d}$ milk protein content $(\mathrm{g} / \mathrm{kg})$ & & $\mathrm{R}^{2}=0.164$ \\
\hline$<31.8$ & 1 & & \\
\hline 31.8 to 33.0 & 1.20 & $0.90-1.62$ & NS \\
\hline 33.1 to 34.4 & 1.52 & $1.10-2.09$ & 0.011 \\
\hline$>34.4$ & 1.54 & $1.10-2.14$ & 0.012 \\
\hline \multicolumn{4}{|l|}{ Protein-to-fat ratio at herd SBD } \\
\hline$<0.81$ & 1 & & \\
\hline 0.81 to 0.90 & 1.34 & $0.98-1.84$ & 0.066 \\
\hline 0.91 to 1.00 & 1.11 & $0.80-1.52$ & NS \\
\hline$>1.00$ & 1.45 & $1.03-2.05$ & 0.036 \\
\hline Model relating BCS variables to likelihood of SR21 & $\mathrm{n}=2204$ & & $\mathrm{R}^{2}=0.131$ \\
\hline \multicolumn{4}{|l|}{ Average BCS between 60 and $100 \mathrm{~d}$ of lactation (BCS units) } \\
\hline$\leq 2.50$ & 0.59 & $0.44-0.78$ & $<0.001$ \\
\hline 2.75 to 3.0 & 1 & & \\
\hline$\geq 3.25$ & 0.90 & $0.63-1.31$ & NS \\
\hline Model relating BW variables to likelihood of SR21 & $\mathrm{n}=1483$ & & $\mathrm{R}^{2}=0.194$ \\
\hline \multicolumn{4}{|l|}{ BW at herd SBD $(\mathrm{kg})$} \\
\hline$<483$ & 1 & & \\
\hline 483 to 529 & 1.33 & $0.82-2.17$ & NS \\
\hline 530 to 576 & 1.20 & $0.70-2.07$ & NS \\
\hline$>576$ & 1.90 & $1.00-3.60$ & 0.048 \\
\hline \multicolumn{4}{|l|}{ BW loss from precalving to nadir $(\mathrm{kg})$} \\
\hline$>131$ & 1 & & \\
\hline 110 to 131 & 1.81 & $1.15-2.86$ & 0.011 \\
\hline 88 to 109 & 1.01 & $0.65-1.55$ & NS \\
\hline$<88$ & 1.17 & $0.72-1.90$ & NS \\
\hline \multicolumn{4}{|l|}{ BW gain from herd SBD to $90 \mathrm{~d}$ thereafter $(\mathrm{kg})$} \\
\hline$<17$ & 1 & & \\
\hline 17 to 34 & 1.08 & $0.69-1.70$ & NS \\
\hline 35 to 52 & 1.64 & $1.00-2.69$ & 0.052 \\
\hline$>32$ & 1.60 & $0.91-2.82$ & 0.100 \\
\hline
\end{tabular}

${ }^{1} \mathrm{SR} 21=$ Submission in the first $3 \mathrm{wk}$ of the breeding season, $\mathrm{OR}=$ odds ratio, $\mathrm{CI}=$ confidence interval, $\mathrm{SBD}=$ herd start of breeding date, $\mathrm{n}=$ number of cows included in analysis, $\mathrm{NS}=P>0.10$.

${ }^{2}$ All models were adjusted for herd, calving period, lactation number, proportion of Holstein-Friesian genes, breeding value for milk yield, and degree of calving assistance.

mated 305-d milk lactose content ( $>46.1 \mathrm{~g} / \mathrm{kg}$; third and fourth quartiles) tended to be associated with an improved likelihood of PREG1 (OR = 1.38, 1.25, $P \leq$ 0.071). Cows that reached nadir milk protein content relatively late in lactation $(>92 \mathrm{~d}$ ) had a lower likelihood of PREG1 $(\mathrm{OR}=0.79, P=0.044)$. This corresponds to an estimated pregnancy rate to first service of 7 percentage units lower than that of cows in the reference category $(<47 \mathrm{~d})$. The adjusted $\mathrm{R}^{2}$ for the model was 0.107 .

\section{BCS, BW, and PREG1}

The only BCS measure significantly associated with the likelihood of PREG1 was nadir BCS (Table 6) (adjusted $R^{2}=0.079$ ). Cows that reached a very low nadir BCS $(\leq 2.5)$ had a reduced likelihood of PREG1 compared with the reference category (2.75 to 3.0). No difference in likelihood for PREG1 $(\mathrm{OR}=0.93)$ was observed with cows that achieved a higher nadir BCS (>3.0) compared with the reference category.
Of the BW variables investigated, those associated with PREG1 were BW at start of breeding date, DIM at which nadir weight occurred, and BW gain between start of breeding and $90 \mathrm{~d}$ thereafter. Cows with a higher BW at the start of breeding date compared with the reference category $(<483 \mathrm{~kg})$ were more likely to have a successful PREG1 $(P \leq 0.015)$. Cows in the reference category for DIM at which nadir weight occurred tended to have a lower likelihood of PREG1 compared with the other three quartiles $(\mathrm{OR}=1.45$, $1.61,1.53, P \leq 0.007)$. Increased BW gain between herd start of breeding date and $90 \mathrm{~d}$ thereafter tended to be positively associated with the likelihood of PREG1. The adjusted $R^{2}$ for the model was 0.102 .

\section{Milk Production and PR42}

A high milk yield at first service was indicative of increased likelihood of being pregnant by $42 \mathrm{~d}$ of the breeding season (Table 7). Both estimated 305-d milk lactose content and estimated 305-d milk protein con- 
Table 6. Association between milk production, BCS and BW variables, and PREG1. ${ }^{1}$

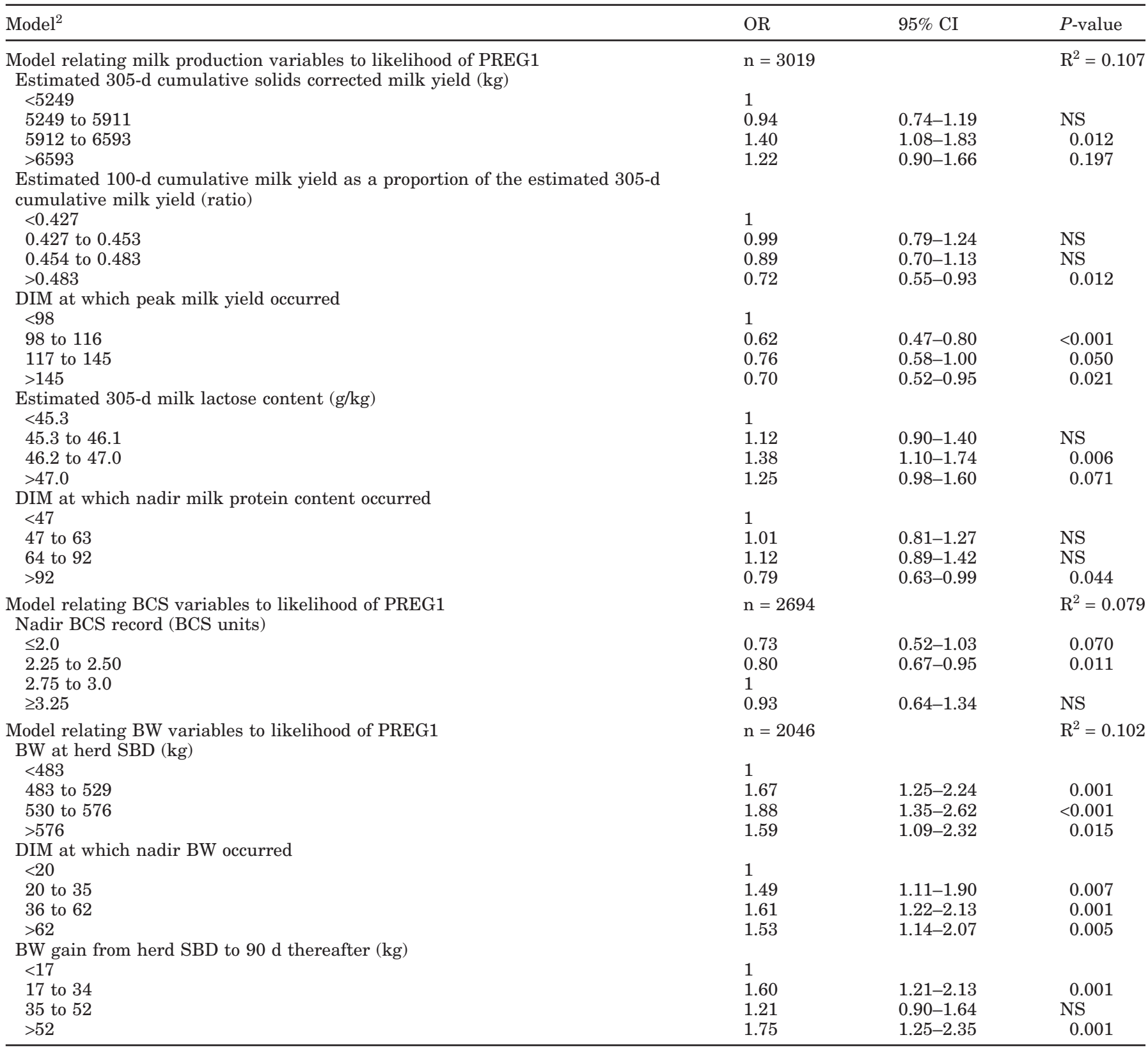

${ }^{1}$ PREG1 = pregnant to first service, $\mathrm{OR}=$ Odds ratio, $\mathrm{CI}=$ confidence interval, $\mathrm{SBD}=$ herd start of breeding date, $\mathrm{n}=$ number of cows included in analysis, $\mathrm{NS}=P>0.10$.

${ }^{2}$ All models were adjusted for herd, calving period, lactation number, proportion of Holstein-Friesian genes, breeding value for milk yield and degree of calving assistance.

tent were positively associated with the likelihood of PR42. Cows in the highest quartile of estimated 305$\mathrm{d}$ milk protein content $(>35.3 \mathrm{~g} / \mathrm{kg})$ had an OR of $1.62(P$ $<0.001$ ), corresponding to an estimated 12-percentagepoint improvement in pregnancy rate after $42 \mathrm{~d}$ of breeding compared with the reference group $(<32.6$ $\mathrm{g} / \mathrm{kg}$ ). Similar to that observed for PREG1 a higher estimated 305-d milk lactose content compared with the reference category $(<45.3 \mathrm{~g} / \mathrm{kg})$ was associated with an improved likelihood of PR42. The adjusted $R^{2}$ for the model was 0.237 .

\section{BCS, BW, and PR42}

An average BCS between 60 and $100 \mathrm{~d}$ of lactation of $\leq 2.5$ was associated with a lower chance of pregnancy 
Table 7. Association between milk production variables, BCS variables and BW variables, and PR42. ${ }^{1}$

\begin{tabular}{|c|c|c|c|}
\hline Model $^{2}$ & OR & $95 \% \mathrm{CI}$ & $P$-value \\
\hline \multicolumn{4}{|l|}{ Yield at first service $(\mathrm{kg} / \mathrm{d})$} \\
\hline$<23.8$ & 1 & & \\
\hline 23.8 to 27.6 & 1.36 & $1.06-1.75$ & 0.017 \\
\hline 27.7 to 31.5 & 1.48 & $1.12-1.96$ & 0.007 \\
\hline$>31.5$ & 1.84 & $1.34-2.52$ & $<0.001$ \\
\hline \multicolumn{4}{|l|}{ Estimated 305-d milk protein content $(\mathrm{g} / \mathrm{kg})$} \\
\hline$<32.6$ & 1 & & \\
\hline 32.6 to 33.8 & 1.18 & $0.93-1.49$ & NS \\
\hline 33.9 to 35.3 & 1.24 & $0.97-1.59$ & 0.085 \\
\hline$>35.3$ & 1.62 & $1.25-2.10$ & $<0.001$ \\
\hline \multicolumn{4}{|l|}{ Estimated 305-d milk lactose content (g/kg) } \\
\hline$<45.3$ & 1 & & \\
\hline 45.3 to 46.1 & 1.40 & $1.10-1.79$ & 0.006 \\
\hline 46.2 to 47.0 & 1.53 & $1.20-1.97$ & 0.001 \\
\hline$>47.0$ & 1.35 & $1.03-1.76$ & 0.029 \\
\hline $\begin{array}{l}\text { Model relating BCS variables to likelihood of PR } 42 \\
\text { Average BCS between } 60 \text { and } 100 \mathrm{~d} \text { of lactation (BCS units) }\end{array}$ & $\mathrm{n}=2569$ & & $\mathrm{R}^{2}=0.210$ \\
\hline$\leq 2.50$ & 0.75 & $0.61-0.93$ & 0.008 \\
\hline 2.75 to 3.0 & 1 & & \\
\hline$\geq 3.25$ & 1.28 & $0.98-1.67$ & 0.071 \\
\hline Model relating BW variables to likelihood of PR42 & $\mathrm{n}=1947$ & & $\mathrm{R}^{2}=0.205$ \\
\hline \multicolumn{4}{|l|}{ BW gain from first service to $90 \mathrm{~d}$ thereafter $(\mathrm{kg})$} \\
\hline$<15$ & 1 & & \\
\hline 15 to 33 & 1.31 & $0.96-1.80$ & 0.092 \\
\hline 34 to 51 & 1.54 & $1.10-2.15$ & 0.011 \\
\hline$>51$ & 2.41 & $1.66-3.50$ & $<0.001$ \\
\hline
\end{tabular}

${ }^{1} \mathrm{PR} 42=$ pregnant after $42 \mathrm{~d}$ of the breeding season, $\mathrm{OR}=$ Odds ratio, $\mathrm{CI}=$ confidence interval, $\mathrm{BCS}=$ body condition score, $\mathrm{BW}=$ body weight, $\mathrm{n}=$ number of cows included in analysis, $\mathrm{NS}=P>0.10$.

${ }^{2}$ All models were adjusted for herd, calving period, lactation number, proportion of Holstein-Friesian genes, breeding value for milk yield and degree of calving assistance.

(PR42) compared with the reference category (2.75 to 3.0) $(\mathrm{OR}=0.75, P=0.008)$ (Table 7). This OR corresponds to an estimated decrease in pregnancy rate after $42 \mathrm{~d}$ of breeding of 7 percentage units compared with the reference category. Cows with an average BCS between 60 and $100 \mathrm{~d}$ of lactation of $\geq 3.25$ tended to have a higher chance of becoming pregnant by $d 42$ of the breeding season $(\mathrm{OR}=1.28, P=0.071)$.

Similar to that observed with both SR21 and PREG1, cows in a more positive energy balance postservice (BW gain between first service and $90 \mathrm{~d}$ thereafter), i.e., gaining $>33 \mathrm{~kg}$, had an increased chance of PR42. Odds ratios of $1.54(P=0.011)$ and $2.41(P<$ 0.001 ) were observed for the third and fourth categories, respectively. These OR values correspond to increases in estimated pregnancy rate after $42 \mathrm{~d}$ breeding of 11 and 21 percentage units, respectively, compared with the reference category. The adjusted $R^{2}$ for the BCS and BW models were 0.267 and 0.205 , respectively.

Analysis of the present dataset using all cows did not identify any of the BCS change variables as potential predictors of likely SR21, PREG1 or PR42. However, when the dataset was restricted to cows with precalving BCS of greater than 3.0 (cows who had BCS to lose), then cows experiencing excessive losses in BCS (>0.5 unit of BCS) were less likely to conceive by $\mathrm{d} 42$ of the breeding season (OR $=0.73, P=0.064)$. This corresponds to an estimated reduction in PR42 of 8 percentage units compared with the reference category $(\leq 0.25$ unit of BCS).

\section{DISCUSSION}

\section{Milk Production and Reproductive Performance}

The present study shows a positive association between milk yield variables and reproductive performance (PREG1 and PR42), when genetic merit for milk yield and proportion of Holstein-Friesian genes are included as adjustment variables. Fulkerson (1984) and Moate and Harris (1983) showed a positive relationship between milk production and reproduction (submission and conception rates) in pasture-based systems. Other studies found no relationship between milk production and reproduction (Villa-Godoy et al., 1988; Raheja et al., 1989). However, most of the recent studies have found an antagonistic relationship between milk production and several fertility traits (Hoekstra et al., 1994; Beam and Butler, 1999; Dar- 
wash et al., 1999; Royal et al. 2000). Milk production may increase due to improved environmental factors, such as better nutrition, health and management, as well as genetic improvement. Pryce and Veerkamp (2001) estimated that about $50 \%$ of the total progress in milk yield in the UK can be attributed to genetic improvement alone. Genetic correlations between milk yield and fertility are negative (see review by Pryce and Veerkamp, 2001); thus, fertility declines with increasing genetic merit for yield. Similarly, Hoekstra et al. (1994) showed that increased proportion of Holstein-Friesian genes was associated with a reduction in nonreturn rates ( $56 \mathrm{~d}$ after $\mathrm{AI}$ ) and pregnancy rate to first service. The results of the present study indicate that after adjustment for factors, such as proportion of Holstein-Friesian genes and genetic potential for milk yield, higher milk production is associated with improved reproductive performance.

In the current study, cows with a very high 100-d cumulative milk yield as a proportion of the estimated 305-d cumulative milk yield (low persistency) were less likely to be pregnant to first service. In addition, cows whose peak milk yield occurred earliest in lactation were more likely to have a successful PREG1. It has been shown previously that very high milk yield at the beginning of lactation (steep lactation curve) puts a high physiological stress on cows, often leading to reproductive disorders (Madsen, 1975). Achieving peak milk yield earlier in lactation would indicate that positive energy balance is being achieved at an earlier stage in lactation.

The results of the present study indicate that milk protein content and days to nadir milk protein content can also be indicative of reproductive performance. Milk protein content or milk protein:fat ratio is often used as an indicator of energy balance. Fulkerson et al. (2001) showed that cows with the lowest milk protein content $(2.89 \%)$ suffered the most severe and prolonged NEB, compared with cows with a milk protein content of $3.10 \%$. Morton (2000) showed that milk protein content was positively associated with submission rate, pregnancy rate to first service, and pregnancy rate after $21 \mathrm{~d}$ breeding in a large field study. In an attempt to establish whether the association observed in the present study was as a result of improved nutrition management or a genetic predisposition for higher protein content, models for SR21 and PR42 were readjusted using the estimated breeding value for protein content. The results (not shown) showed that protein content remained positively associated with the likelihood of SR21 and PR42. Auldist et al. (2000) demonstrated that milk protein content was reduced with lower DMI.
Milk lactose concentration has been shown to be associated with resumption of luteal function in second-parity Norwegian dairy cattle (Reksen et al., 2002). In the present study a higher 305-d lactose content was associated with an increased likelihood of both PREG1 and PR42. Because milk lactose is derived almost entirely from plasma glucose, it is possible that milk lactose concentration could be used as a possible indicator of energy balance and consequently reproductive performance.

In Ireland, the normal industry practice is to start breeding on a fixed date (late April to early May) and also to finish lactation on a fixed date (early to late December). Depending on the calving pattern, this will result in large variation in lactation length and a possible reason for milk yield at first service, better reflecting likely reproductive performance than estimated total lactation milk yield. Milk protein content, on the other hand, is a component very much associated with energy balance (Fulkerson et al., 2001). The estimated total lactation protein content was perhaps a better indicator of the overall level of nutritional management on farms rather than a single measure, which could be influenced by fluctuations in grass supply/grazing conditions.

The positive relationship between milk production and the reproductive traits suggests that a proportion of cows in the present study were being underfed in early lactation. Such underfeeding prevented the animals' reaching their genetic production potential, while at the same time limiting their reproductive performance. This hypothesis is supported by the BCS results.

\section{BCS, BW, and Reproductive Performance}

The results of this study highlight the importance of BCS in achieving good reproductive performance. Simple linear regression showed a decrease in BCS at first service of 0.06 unit per $100-\mathrm{kg}$ increase in genetic merit for milk yield $(P<0.001)$ and 0.003 unit per 1 unit increase in proportion of Holstein-Friesian genes $(P<0.001)$, respectively. Similarly, BCS loss between precalving and first service was increased by 0.02 unit per $100 \mathrm{~kg}$ increase in genetic merit for milk yield ( $P$ $=0.001)$ and 0.001 unit per unit increase in proportion of Holstein-Friesian genes $(P<0.001)$, respectively. These effects were adjusted for in the analysis. Body condition scores and BCS change seem to affect reproductive performance because they are indicators of the degree of NEB occurring in early lactation (Butler and Smith, 1989). The results reported here are consistent with the hypothesis of Britt (1992), who suggested that NEB during early postpartum folliculogenesis could 
impair follicular development and subsequent reproductive performance. Britt (1992) suggested that the production of defective follicles during the breeding period may result in low plasma concentrations of progesterone and be associated with low fertility. Previous studies have often, but not always, found a negative relationship between BCS or BCS change and reproductive performance (see review by Stockdale, 2001). The variability in results relating BCS to reproductive performance may be related to animal numbers but also to the system of milk production. For example, Garnsworthy and Topps (1982), Treacher et al., (1986), Garnsworthy and Jones (1987), and Jones and Garnsworthy (1988) reported no significant differences between cows with different BCS at calving and days to first estrus, days to conception, and number of inseminations to conceive. Garnsworthy (1988) concluded that it was not necessary to achieve a BCS of 3 to 3.5 (scale 1 to 5 ) at calving and that any BCS between 2 and 3 would be sufficient to achieve good reproductive performance. However, most of this research was conducted with high concentrate, complete diets fed indoors. In contrast, Grainger et al. (1982) found that improvements in BCS reduced the postpartum anestrous interval by $5.7 \mathrm{~d}$ for each additional condition score at calving in pasture-based systems of milk production. In the present study, BCS precalving was not significantly associated with reproductive performance. The likelihood of reproductive success was best predicted by BCS around the time of first service and for cows calving in good BCS, BCS loss between calving and first service. This is similar to the findings of Gillund et al. (2001) with Norwegian dairy cattle. That study found no association between BCS at calving and subsequent reproductive performance; however, it showed that cows that experienced marked losses in BCS during the postpartum period were half as likely to conceive to first service as cows that experienced modest losses in BCS. In the same study, BCS loss postcalving was associated with a prolonged calving-to-conception interval. A similar observation was made by Suriyasathaporn et al. (1998). Pryce et al. (2001) showed that a 1-unit increase in phenotypic BCS at wk 10 of lactation was associated with 6.2 $\mathrm{d}$ less to first service and 9 percentage units higher conception rate to first service. In the same study a 1unit improvement in phenotypic BCS change between wk 1 and 10 of lactation was associated with a reduction in calving to first service interval of $10.6 \mathrm{~d}$ and 9 percentage units higher conception rate to first service $(P=0.06)$.

Precalving BCS was not associated with the fertility variables investigated in the current study. However, it does influence BCS change in early lactation. A BCS loss of greater than 0.5 BCS unit between precalving and first service occurred in 30,47 , and over $60 \%$ of cows that had a precalving BCS of $3.25,3.5$, and greater than 3.5, respectively. On the basis of this, a precalving BCS of no greater than 3.25 is a sensible target for pasture-based spring calving systems in Ireland.

There was good agreement between the BW and BCS variables in their association with reproductive performance in the present study. Studies by Youden and King (1977) showed that BW change around mating did influence conception rate with the conception rate being $62 \%$ for cows gaining BW but only $47 \%$ for those losing BW. Fulkerson et al. (2001) found a positive relationship between BW gain 4 wk before the start of mating and pregnancy rate after $24 \mathrm{~d}$ of the mating period. Cows that became pregnant gained $0.95 \mathrm{~kg}$, while nonpregnant cows gained $0.4 \mathrm{~kg}$ in that period.

\section{CONCLUSIONS}

The results show a positive relationship between dairy cow reproductive performance (likelihood of submission and pregnancy) and milk production in a pasture-based system when adjustments include breeding value for milk yield and proportion of HolsteinFriesian genes. It is also clear that on a seasonal pasture-based system of milk production it is necessary to maintain BCS at 2.75 or greater during the breeding season. Loss of body condition between calving and first service should be restricted to 0.5 BCS unit to avoid a detrimental effect on reproductive performance. The results of the present study show also that milk protein and lactose content, and BW gain postbreeding are important tools to identify cows at risk of poor reproductive performance.

\section{ACKNOWLEDGMENTS}

The authors acknowledge the financial support of AIB Bank, Holstein UK and Ireland, the National AI Co-ops and Dairy Levy funding. The technical assistance of D. Cliffe, T. Condon, J. Kenneally, K. O’Malley, D. Butler, and the many UCD summer students is also acknowledged. This study would not have been possible without the support of the 74 commercial dairy farmers. The authors acknowledge their cooperation in relation to access to their dairy herds and to their farm records.

\section{REFERENCES}

Auldist, M. J., N. A. Thomson, T. R. Mackle, J. P. Hill, and C. G. Prosser. 2000. Effects of pasture allowance on the yield and 
composition of milk from cows of different $\beta$-Lactoglobulin phenotypes. J. Dairy Sci. 83:2069-2074.

Bauman, D. E., and W. B. Currie. 1980. Partitioning of nutrients during pregnancy and lactation: a review of mechanisms involving homeostasis and homeorhesis. J. Dairy Sci. 63:1514-1529.

Beam, S. W., and W. R. Butler. 1999. Energy balance effects on follicular development and first ovulation in post-partum cows. J. Reprod. Fertil. 54(Suppl.):411-424.

Britt, J. H. 1992. Impacts of early postpartum metabolism on follicular development and fertility. Proc. Am. Assoc. Bovine Pract. 24:39-43.

Buckley, F., P. Dillon, S. Crosse, F. Fynn, and M. Rath. 2000a. The performance of Holstein-Friesian dairy cows of high and medium genetic merit for milk production on grass based feeding systems. Livest. Prod. Sci. 64:107-119.

Buckley, F., P. Dillon, M. Rath, and R. F. Veerkamp. 2000b. The relationship between genetic merit for yield and live-weight, condition score, and energy balance of Spring-calving HolsteinFriesian dairy cows on grass-based system of milk production. J. Dairy Sci. 83:1878-1886.

Butler, W. R., and R. D. Smith. 1989. Interrelationships between energy balance and postpartum reproductive function in dairy cattle. J. Dairy Sci. 72: 767-783.

Cowan, R. T. 1982. An interpretation of responses in milk yield of dairy cows to increased levels of feeding during late pregnancy. Pages 409-412 in Proc. 14th Australian Soc. Anim. Prod. Conf. Pergamon Press, Sydney.

Crosse, S. 1986. The development and implementation of a computerised management information system for Irish dairy farmers. Ph.D. Thesis. National University of Ireland.

Darwash, A. O., G. E. Lamming, and J. A. Woolliams. 1999. The potential for identifying heritable endocrine parameters associated with fertility in post-partum dairy cows. J. Anim. Sci. 68:333-347.

Department of Agriculture, Food and Forestry. 1994. National breeding programme for dairy cattle. Page 5 in Annual report.

Dillon, P., S. Crosse, G. Stakelum, and F. Flynn. 1995. The effect of calving date and stocking rate on the performance of springcalving dairy cows. Grass Forage Sci. 50:286-299.

Domecq, J. J., A. L. Skidmore, J. W. Lloyd, and J. B. Kaneene. 1997. Relationship between body condition scores and milk yield in a large dairy herd of high yielding Holstein cows. J. Dairy Sci. 80:101-112

Fulkerson, W. J. 1984. Reproduction in dairy cattle: effect of age, cow condition, production level, calving to first service interval and the 'male'. Anim. Reprod. Sci., 7:305-314.

Fulkerson, W. J., J. Wilkins, R. C. Dobos, G. M. Hough, M. E. Goddard, and T. Davidson. 2001. Reproductive performance in Holstein-Friesian cows in relation to genetic merit and level of feeding when grazing pasture. J. Anim. Sci. 73:397-406.

Garnsworthy, P. C., and J. H. Topps. 1982. The effect of body condition of dairy cows at calving on their food intake and performance when given complete diets. Anim. Prod. 35:113.

Garnsworthy, P. C., and G. P. Jones. 1987. The influence of body condition at calving and dietary protein supply on voluntary food intake and performance in dairy cows. Anim. Prod. 44:347-353.

Garnsworthy, P. C. 1988. The effect of energy reserves at calving on performance of dairy cows. Page 17 in Nutrition and Lactation in the dairy cow. Butterworths, London, England.

Gibb, M. J., W. E. M. Irvings, S. Dhanoa, and J. D. Sutton. 1992. Changes in body components of autumn-calving HolsteinFriesian cows over the first 29 weeks of lactation. Anim. Prod. 55:339-360.

Gillund, P., O. Reksen, Y. T. Gröhn, and K. Karlberg. 2001. Body condition related to ketosis and reproductive performance in Norwegian dairy cattle. J. Dairy Sci. 84:1390-1396.

Grainger, C., G. D. Wilhelms and A. A. McGowan. 1982. Effect of body condition at calving and level of feeding in early lactation on milk production of dairy cows. Aust. J. Exp. Agric. Anim. Husbandry 22:9-17.

Grainger, C., A. W. F. Davey, and C. W. Holmes. 1985. Performance of Friesian cows with high and low breeding indexes. 1. Stall feeding and grazing experiments and performance during the whole lactation. Anim. Prod. 40:379-388.

Hoekstra, J., A. W. Van der Lugt, J. H. J. Van der Werf, and W. Ouweltjes. 1994. Genetic and phenotypic parameters for milk production and fertility traits in upgraded dairy cattle. Livest. Prod. Sci. 40:225-232.

Jones, G. P., and P. C. Garnsworthy. 1988. The effects of body condition at calving and dietary protein content on dry matter intake and performance in lactating dairy cows given diets of low energy content. Anim. Prod. 47:321-333.

Kleinbaum, D. G. 1994. Logistic Regression, Springer-Verlag, New York.

Lowman, B. G., N. Scott, and S. Somerville. 1976. Condition scoring of cattle. Rev. Ed. Bull. East Scotland College of Agriculture, No. 6.

Madsen, O. 1975. A comparison of some suggested measures of persistency of milk yield in dairy cows. Anim. Prod. 20:191-197.

Mee, J. F., J. Fahey, and J. Crilly. 1999. Breeding the dairy cow of the future-Today's challenges. Pages 7-16 in Dairying in the new millennium. Teagasc Natl. Dairy Conf., Adare.

Moate, P. J., and D. J. Harris. 1983. A survey to determine the influence of cow condition score, calving to service interval, age and milk yield on cow fertility. Pages 106-108 in Dairy Production Report. Dairy Research Institute, Ellinbank, Australia.

Montgomery, D. C., E. A. Peck, and G. G. Vinning. 2001. Introduction to linear regression analysis, 3rd ed. John Wiley \& Sons, Inc., New York, NY.

Morton, J. 2000. The Incalf Project. Progress Report No. 2. Dairy Research and Development Corporation, Melbourne, Australia. ISBN 0642 44918X.

Nagelkerke, N. J. D. 1991. A note on a general definition of the coefficient of determination. Biometrika 78:691-692.

Nebel, R. L., and M. L. McGilliard. 1993. Interactions of high milk yield and reproductive performance in dairy cows. J. Dairy Sci. 76:3257-3268.

O'Farrell, K. J. 1994. Measurement of fertility in seasonally-calving dairy herds. $\mathrm{R} \& \mathrm{H}$ Hall Technical Bulletin Issue No. 2. $\mathrm{R} \& \mathrm{H}$ Hall, Dublin, Ireland.

Pryce, J. E., and R. F. Veerkamp. 2001. The incorporation of fertility indices in genetic improvement programmes. BSAS occasional meeting 'Fertility in high producing dairy cow', 10-22 September 1999, Galway. BSAS publication 26 (I):237-249.

Pryce, J. E., M. P. Coffey, and G. Simm. 2001. The relationship between body condition score and reproductive performance. J. Dairy Sci. 84:1508-1515.

Raheja, K. L., E. B. Burnside, and L. R. Schaeffer. 1989. Relationship between fertility and production in Holstein dairy cattle in different lactations. J. Dairy Sci. 72:2670-2678.

Reksen, O., Ø. Havrevoll, Y. T. Gröhn, T. Bolstad, A. Waldmann, and E. Ropstad. 2002. Relationships among body condition score, milk constituents, and postpartum luteal function in Norwegian dairy cows. J. Dairy Sci. 85:1406-1415.

Royal, M. D., A. O. Darwash, A. P. F. Flint, R. Webb, J. A. Woolliams and G. E. Lamming. 2000. Declining fertility in dairy cattle: changes in traditional and endocrine parameters of fertility. J. Anim. Sci. 70:487-501.

Senatore, E. M., W. R. Butler, and P. A. Olenacu. 1996. Relationships between energy balance and post-partum ovarian activity and fertility in first lactation dairy cows. J. Anim. Sci. 62:17-23.

SPSS, Inc. 1999. SPSS Regression Models 10.0. Chicago: M. J. Norušis.

Stockdale, C. R.. 2001. Body condition at calving and the performance of dairy cows in early lactation under Australian conditions: a review. Aust. J. Exp. Agric., 41:823-839.

Suriyasathaporn, W., M. Nielsen, S. J. Dieleman, A. Brand, E. N. Noordhuizen-Stassen, and Y. H. Schukken. 1998. A Cox proportional-hazards model with time dependent covariates to evaluate the relationship between body-condition score and the risks of first insemination and pregnancy in a high-producing dairy herd. Preventative Vet. Med. 37:159-172. 
Treacher, R. J., I. M. Reid, and C. J. Roberts. 1986. Effect of body condition at calving on the health and performance of dairy cows. Anim. Prod. 43:1.

Veerkamp, R. F., G. Simm, and J. D. Oldham. 1994. Effects of interaction between genotype and feeding system on milk production, feed intake, efficiency and body tissue mobilisation in dairy cows. Livest. Prod. Sci. 39:229-241.

Veerkamp, R. F., and S. Brotherstone, 1997. Genetic correlations between linear type traits, feed intake, live weight and condition score in Holstein Friesian dairy cattle. J. Anim. Sci. 64:385-392.
Veerkamp, R. F., E. P. C. Koenen and G. de Jong. 2001. Genetic correlations among body condition score, yield, and fertility in first-parity cows estimated by random regression models. J. Dairy Sci. 84:2327-2335.

Villa-Godoy, A., T. L. Hughs, R. S. Emery, L. T. Chapin, and R. L. Fogwell. 1988. Associations between energy balance and luteal function in lactating dairy cows. J. Dairy Sci. 71:1063.

Youden, P. G., and J. O. L. King. 1977. The effect of body weight changes on fertility during the post-partum period in dairy cows. Br. Vet. J. 133:635. 